\title{
An Improved Method for Purification of Turnip Mosaic Virus
}

\author{
Jang Kyung Chö*, Takanori MAedA** and Satoshi WAKImoto* \\ 崔＼cjkstart璋京・前田孚憲・脇本 哲：カブモザイクウイルスの純化方法について
}

\begin{abstract}
An improved method for purification of turnip mosaic virus (TuMV) was established. The infected turnip leaves were frozen and homogenized with $0.5 \mathrm{M}$ potassium phosphate buffer, $\mathrm{pH} 7.5$, containing $0.01 \mathrm{M}$ Na-EDTA and $0.1 \%$ thioglycolic acid. The crude sap obtained by low-speed centrifugation was simultaneously added with $1 \%$ Triton $\mathrm{X}-100,4 \%$ polyethylene glycol ( $\mathrm{MW} \mathrm{6,000)}$ and $0.1 \mathrm{M} \mathrm{NaCl}$ to precipitate TuMV without tight aggregation of the virus particles. The pellet was resuspended in high molarity $(0.5 \mathrm{M})$ potassium phosphate buffer added with $0.01 \mathrm{M} \mathrm{MgCl}_{2}$. The resuspension fluid was treated further by one cycle of differential centrifugation followed by sucrose density-gradient centrifugation. The purified TuMV thus obtained showed the following characteristics ; O. D. 260 / O. D. 280 ratio of 1.23 , max. 260 / min. 247 ratio of 1.14 and particle length of $745 \mathrm{~nm}$. The yield of purified virus was $1.5-4.0 \mathrm{mg} / 100 \mathrm{~g}$ infected turnip leaves. Not any contaminants from host materials were observed in the purified preparation under electron microscopy.
\end{abstract}

(Received June 8,1977)

\section{Introduction}

A number of reports have indicated that purification of filamentous viruses which belong to potato virus $\mathrm{Y}$ (PVY) group is difficult because of their properties of aggregation and instability during the purification process. Especially, aggregation is a serious problem encountered frequently $2,3,10$ ).

Recently, considerable improvements were made in the methods for purification of plant viruses. Stace-Smith and Tremaine ${ }^{20}$ ) reported that the aggregation of PVY during the purification process was prevented by using high molarity phosphate buffer. Nozu and Yamamura ${ }^{13}$ ) successfully purified tobacco mosaic virus by using a detergent, Triton X-100 (alkylphenoxypolyethoxyethanol). Hull and Shepherd ${ }^{8}$ ) also applied it for purification of cauliflower mosaic virus. Polyethylene glycol (PEG) has also been described useful for purification of many viruses including PVY group members ${ }^{3,6)}$, though its mechanism is quite different from that of detergents.

Several methods have been reported for partial purification of turnip mosaic virus (TuMV) ${ }^{19,22)}$, and yet more simple and reliable method is required. In order to establish an improved method for purification of TuMV from infected plants, investigations were made step by step.

* Faculty of Agriculture, Kyushu University, Fukuoka 812, Japan 九州大学農学部

** Present address : Institute for Agricultural and Biological Sciences, Okayama University, Kurashiki 710, Japan 岡山大学農業生物研究所 


\section{Materials, Methods and Results}

\section{Virus strain and its propagation}

An ordinary strain of TuMV, isolate No. 6725) maintained on turnip (Brassica rapa L.) by successive inoculation in our laboratory was used. Virus was propagated with $B$. rapa L. var. glabra Kitamura cv. Hakatasuwari grown in a temperature controlled greenhouse at around $25 \mathrm{C}$. The plants in 4-5 leaf stage were dusted with Carborundum (400 mesh) and inoculated with crude sap prepared by grinding infected leaves with an equal volume $(\mathrm{w} / \mathrm{v})$ of $0.1 \mathrm{M}$ phosphate buffer, $\mathrm{pH}$ 7.0. Systemically infected leaves were harvested 15-20 days after inoculation and frozen at $-21 \mathrm{C}$ for a few days prior to use. Freezing of the infected leaf materials made grinding easy and denatured the host constituents without reducing yield or infectivity of TuMV.

\section{Bioassay of TuMV infectivity}

Both Nicotiana tabacum L. cv. Samsun nc and Chenopodium amaranticolar were known to be local lesion hosts of TuMV. In order to compare both plants in suitability for assaying TuMV infectivity, inoculation tests were made preliminary. The crude sap prepared by grinding infected turnip leaves with $0.1 \mathrm{M}$ phosphate buffer, $\mathrm{pH} 7.0$, was diluted serially with the same buffer, and each diluent was used as inoculum.

Both inoculated plants produced almost the same number of local lesions at each dilution, however, the periods necessary for lesion development were much different depending on the plants. N. tabacum cv. Samsun nc required about 5 days for lesion appearance while $C$. amaranticolar about two weeks. In order to assay TuMV concentration, therefore, an ordinary half-leaf method on Samsun nc by using 12-16 fully expanded leaves for each sample was applied, repeating two times in each experiment.

\section{Buffers for TuMV extraction}

In order to find out suitable buffer for extraction of TuMV from the infected turnip leaves, the infectivities of the extracts prepared with various molarities of potassium phosphate buffer, $\mathrm{pH} 7.5^{19}$ ), and borate buffer, $\mathrm{pH} 8.0^{23}$ ), were compared with each other. Twenty grams of frozen leaves were ground with $24 \mathrm{ml}$ of each buffer in a morter and pestle and the homogenized suspension was squeezed through two layers of cheesecloth. The supernatant obtained by centrifugation at $8,500 \times$ $g$ for $10 \mathrm{~min}$ was centrifuged again at $65.900 \times g$ for $90 \mathrm{~min}$. The pellet was res-

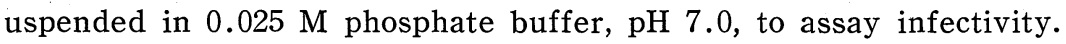

Regardless of the kind of buffer, phosphate or borate, high molarity was superior to low molarity in extraction efficiency, and the extract with $0.5 \mathrm{M}$ potassium phosphate buffer showed the highest infectivity (Table 1). The extracts obtained with high molarity buffers showed deeper green as compared to those with low molarity buffers.

The effect on extraction efficiency of some reducing and chelating agents such as $0.01 \mathrm{M}$ tetrasodium ethylenediamine tetraacetic acid (Na-EDTA), $0.01 \mathrm{M}$ sodium diethyldithiocarbamate (Na-DIECA) ${ }^{20)}, 0.1 \%$ thioglycolic acid ${ }^{16)}, 1 \%$ 2-mercaptoethanol ${ }^{3)}$ and $0.3 \%$ ascorbic acid were tested by adding to $0.5 \mathrm{M}$ potassium phosphate extraction buffer. In these experiments, the extract obtained by $0.5 \mathrm{M}$ phosphate buffer added with $0.1 \%$ thioglycolic acid gave 2-3 fold higher infectivity than others. It is well known that metallic ions originated from host tissue or metallic impurities from some reagents might decrease the reducing action of thioglycolic $\operatorname{acid}^{23}$. To avoid this possibility, $0.01 \mathrm{M}$ Na-EDTA was previously added to the buffer in prac- 
Table 1. Effect of various buffers on extracting TuMV from Brassica rapa leaves

\begin{tabular}{|c|c|c|}
\hline \multirow{2}{*}{ Treatment } & \multicolumn{2}{|c|}{ Relative infectivity $\left.{ }^{b}\right)$} \\
\hline & Expt. 1 & Expt. 2 \\
\hline $0.5 \mathrm{M}$ phosphate $\left.{ }^{a}\right)(\mathrm{pH} 7.5)$ & 436 & 411 \\
\hline $0.1 \mathrm{M}$ phosphate $(\mathrm{pH} 7.5)$ & 100 & 100 \\
\hline $0.05 \mathrm{M}$ phosphate (pH 7.5) & 68 & 65 \\
\hline $0.5 \mathrm{M}$ borate $(\mathrm{pH} 8.0)$ & 89 & 107 \\
\hline $0.05 \mathrm{M}$ borate $(\mathrm{pH} 8.0)$ & 5 & 3 \\
\hline
\end{tabular}

a) Potassium monobasic- and dibasic-phosphate were used.

b) The crude sap in each buffer was differentially centrifuged at $8,500 \times g$ for 10 min and at $65,900 \times g$ for $90 \mathrm{~min}$. The final pellet was resuspended in $0.025 \mathrm{M}$ phosphate buffer, $\mathrm{pH} 7.0$, and assayed for infectivity.

tical application. Thioglycolic acid plus Na-EDTA did not reduce the infectivity.

\section{Clarification}

The supernatants of leaf homogenate obtained by centrifugation at $3,200 \times g$ for 10 min were clarified by means of several standard methods. As shown in Table 2 , the treatment by $1 \%$ Triton $\mathrm{X}-100^{13}$ ) or $10 \%$ activated charcoal ${ }^{2)}$ gave highly infectious preparations, but the latter caused contamination with green host materials and charcoal powders. The treatment by organic solvent such as $8 \% n$-butanol $^{19)}$ or $1 / 2$ volume $(\mathrm{v} / \mathrm{v})$ chloroform $^{14)}$ resulted clear and yellowish solution, however, these treatments reduced infectivity nearly to one-half as compared to those treated with Triton $\mathrm{X}-100$. Acidification ( $\mathrm{pH} \mathrm{5.0})^{15,19)}$ and bentonite $(1 / 5 \text { volume })^{4)}$ gave the best effect on clarification but the infectivity was lost remarkably.

Table 2. Effect of clarification treatments on infectivity of TuMVa)

\begin{tabular}{|c|c|c|c|}
\hline \multirow{2}{*}{ Treatment } & \multirow{2}{*}{ Final suspension ${ }^{b}$ ) } & \multicolumn{2}{|c|}{ Relative infectivity } \\
\hline & & Expt. 1 & Expt. 2 \\
\hline None & green & 100 & 100 \\
\hline Freezing $(-21 \mathrm{C}, 4 \mathrm{hr})$ & green & 94 & $-c)$ \\
\hline Acidification ( $\mathrm{pH} \mathrm{5.0)}$ & faint yellow & 14 & - \\
\hline Butanol $(8 \%)$ & yellow & 79 & - \\
\hline Chloroform ( $1 / 2$ vol.) & yellow & 100 & - \\
\hline Bentonite (1/5 vol.) & faint yellow & - & 30 \\
\hline Charcoal $(10 \%)$ & green & 205 & 160 \\
\hline Triton X-100 (1\%) & yellowish green & 198 & 165 \\
\hline
\end{tabular}

a) The original suspension was prepared by homogenizing infected turnip leaves with $0.5 \mathrm{M}$ phosphate buffer containing $0.01 \mathrm{M} \mathrm{Na-EDTA}$ and $0.1 \%$ thioglycolic acid.

b) The treated suspension was differentially centrif uged at $8,500 \times g$ for 10 min and at $65,900 \times g$ for $90 \mathrm{~min}$. Then final pellet was resuspended in $0.025 \mathrm{M}$ phosphate buffer.

c) Not tested.

\section{PEG precipitation combined with clarification methods}

Polyethylene glycol (PEG, MW 6,000) have been effectively applied for purification of many viruses including some of PVY group ${ }^{3,6,21)}$. To find out the best condi- 
tions for PEG application, the supernatant fluid obtained by low-speed centrifugation of leaf homogenate was added with PEG and sodium chloride at various concentrations. After stirring for $30 \mathrm{~min}$, these preparations were incubated for $2 \mathrm{hr}$ or more and centrifuged at $8,500 \times g$ for $15 \mathrm{~min}$. Pellets were resuspended in $0.025 \mathrm{M}$ phosphate buffer, $\mathrm{pH} 7.0$, to assay their infectivities. The highest yield of TuMV was obtained similarly in two repetitions with the combination of $4 \%$ PEG and 0.1 $\mathrm{M} \mathrm{NaCl}$. By the following low-speed centrifugation, however, abundant loss of virus in the supernatant was resulted, suggesting that tight aggregation of the virus particles with each other or with host materials occurred due to PEG treatment ${ }^{8)}$.

To prevent this undesirable phenomenon, the effects of PEG precipitation combined with several clarification treatments were tested. The mixture was stirred for $2-3 \mathrm{hr}$ at room temperature and centrifuged at $8,500 \times g$ for $15 \mathrm{~min}$. The pellet was then resuspended in $0.025 \mathrm{M}$ phosphate buffer and centrifuged again at lowspeed to obtain supernatant. As shown in Table 3, the concurrent addition of Triton $\mathrm{X}-100, \mathrm{PEG}$ and $\mathrm{NaCl}$ to the supernatant obtained from leaf homogenate to make final concentrations of $1 \%, 4 \%$ and $0.1 \mathrm{M}$, respectively, gave the highest yield. Although charcoal treatment followed by PEG precipitation also gave good result in respect of virus yield, the green materials and charcoal powders remained in the final preparation. The combination of bentonite with PEG was reported to be highly effective for concentrating flexuous rod-shaped viruses $\left.{ }^{4}, 10\right)$, however, the method was not suited for TuMV. The combination of $n$-butanol with PEG / $\mathrm{NaCl}$ treatment showed similar result with $\mathrm{PEG} / \mathrm{NaCl}$ treatment alone.

Table 3. Effect of PEG treatment combined with clarification methods on recovery of TuMV

\begin{tabular}{|c|c|c|}
\hline \multirow{2}{*}{ Treatment } & \multicolumn{2}{|c|}{ Relative infectivityf) } \\
\hline & Expt. 1 & Expt. 2 \\
\hline $\left.\mathrm{PEG} / \mathrm{NaCl}^{\mathrm{a}}\right)$ & 100 & 100 \\
\hline PEG / $\mathrm{NaCl}$ after butanol treatment ${ }^{\mathrm{b})}$ & 109 & 84 \\
\hline PEG / $\mathrm{NaCl}$ after bentonite treatment ${ }^{\mathrm{c}}$ ) & $-g)$ & 38 \\
\hline PEG / $\mathrm{NaCl}$ after charcoal treatment ${ }^{\mathrm{d}}$ ) & 114 & 200 \\
\hline Triton $\mathrm{X}-100 / \mathrm{PEG} / \mathrm{NaCl} \mathrm{e})$ & 142 & 215 \\
\hline
\end{tabular}

a) $\mathrm{PEG} 4 \%, \mathrm{NaCl} 0.1 \mathrm{M}$.

b) -d) See Table 2 .

e) Triton $\mathrm{X}-100(1 \%)$ was also concurrently added to a).

f) The pellet obtained by low-speed centrifugation was resuspended in $0.025 \mathrm{M}$ phosphate buffer. Then the suspension was centrifuged again at a low-speed. The supernatant thus obtained was inoculated.

g) Not tested.

\section{Resuspending buffers}

Recently, high molarity buffer was occasionally used for resuspending PVY group viruses in purification procedures ${ }^{5,11)}$. To find out suitable buffer for resuspending TuMV, potassium phosphate buffer of high $(0.5 \mathrm{M})$ and low $(0.05 \mathrm{M})$ molarities were tested. Additional effects of urea ${ }^{3,7,24)}, \mathrm{MgCl}_{2}{ }^{1)}$ and EDTA ${ }^{11}$ ) at final concentrations of $0.5,0.01$ and $0.005 \mathrm{M}$, respectively, were also tested. The pellets obtained by Triton X-100 / PEG / NaCl treatment followed by low-speed centrifugation were resuspended in $0.5 \mathrm{M}$ or $0.05 \mathrm{M}$ potassium phosphate buffers, $\mathrm{pH} 7.5$, with or without additives, and were given one cycle of differential centrifugation $(8,500$ 
$\times g$ for $10 \mathrm{~min}$ and $65,900 \times g$ for $90 \mathrm{~min}$ ). The final pellets were resuspended in respective buffers and were assayed for their infectivities after low-speed centrifugation. Markedly higher infectivity was recovered in the supernatant when high molarity buffer was used (Table 4). The addition of $\mathrm{MgCl}_{2}$ or urea to high molarity potassium phosphate buffer was effective in preventing aggregation to give high yield of virus, while EDTA did not. Urea in low molarity buffer decreased the infectivity.

Table 4. Effect of supplements added to resuspending buffer on preventing aggregation of TuMV

\begin{tabular}{l|c|c}
\hline \multicolumn{1}{c|}{ Treatment $^{\mathrm{a})}$} & \multicolumn{2}{c}{ Relative infectivity } \\
\hline & Expt. 1 & Expt. 2 \\
\hline $0.5 \mathrm{M}$ phosphate & 100 & 100 \\
$0.5 \mathrm{M}$ phosphate containing $0.01 \mathrm{M} \mathrm{MaCl}_{2}$ & 149 & 211 \\
$0.5 \mathrm{M}$ phosphate containing $0.5 \mathrm{M}$ urea & 158 & 144 \\
$0.5 \mathrm{M}$ phosphate containing $0.005 \mathrm{M} \mathrm{EDTA}$ & 108 & 107 \\
$0.05 \mathrm{M}$ phosphate & 2 & 7 \\
$0.05 \mathrm{M}$ phosphate containing $0.01 \mathrm{M} \mathrm{MgCl}{ }_{2}$ & 41 & 50 \\
$0.05 \mathrm{M}$ phosphate containing $0.5 \mathrm{M}$ urea & 0.7 & 0.7 \\
$0.05 \mathrm{M}$ phosphate containing $0.005 \mathrm{M} \mathrm{EDTA}$ & 8 & 64
\end{tabular}

a) The pellet obtained by Triton $\mathrm{X}-100 / \mathrm{PEG} / \mathrm{NaCl}$ treatment and one cycle of the differential centrifugation was resuspended in each buffer. $\mathrm{pH}$ was adjusted to 7.5 .

b) Supernatant obtained by low-speed centrifugation was assayed.

\section{Sucrose density-gradient centrifugation}

Rate zonal density-gradient centrifugation was carried out in a Spinco SW 25.1

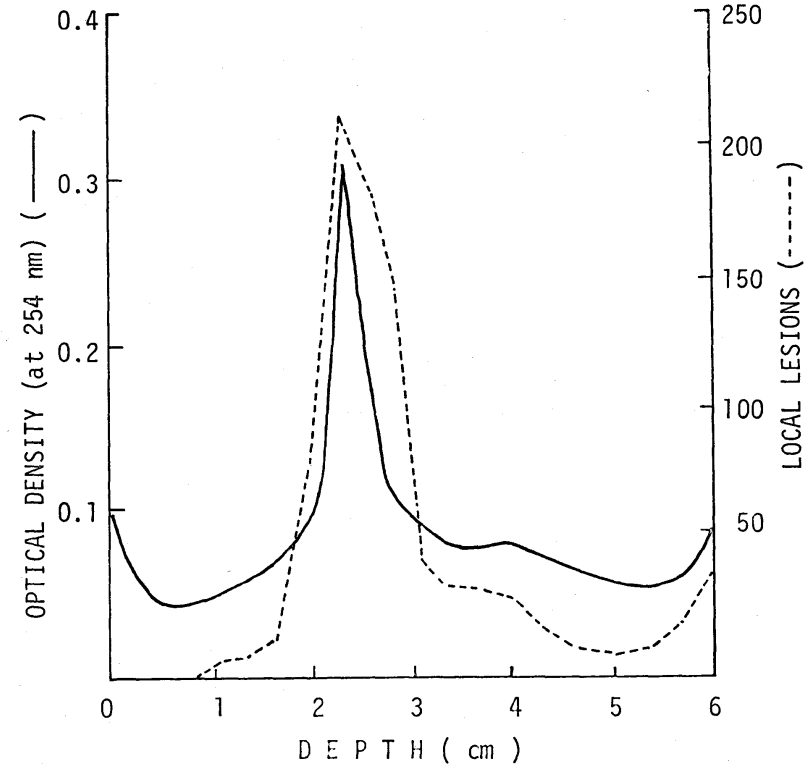

Fig. 1 Infectivity and UV absorption profile after sucrose density-gradient centrifugation. rotor. Sucrose column was prepared by layering $4,7,7$ and $7 \mathrm{ml}$ each of $10,20,30$ and $40 \%$ $(\mathrm{w} / \mathrm{v})$ sucrose in $0.5 \mathrm{M}$ potassium phosphate buffer, $\mathrm{pH} 7.5$, containing $0.01 \mathrm{M} \mathrm{MgCl}_{2}$. The column was allowed to stand overnight at $4 \mathrm{C}$ prior to use. Partially purified virus preparation was laid on the column and centrifuged at $61,000 \times g$ for $2 \mathrm{hr}$. Single light-scattering zone appeared at about 22$24 \mathrm{~mm}$ depth from the meniscus. The column was fractionated by a LKB 7000 Ultro Rac fractionator, and both infectivity and ultraviolet absorption of each fraction were determined. As shown in Fig. 1, the infectivity was closely associated with the optical density at $254 \mathrm{~nm}$. 
Light-scattering zone collected from sucrose density-gradient column was diluted with $0.01 \mathrm{M}$ phosphate buffer, $\mathrm{pH} 7.0$, and was reconcentrated by centrifugation at $69,600 \times g$ for $90 \mathrm{~min}$ in a Spinco No. 40 rotor. The pellet was resuspended in the same buffer, and purified virus preparation was obtained as supernatant of centrifugation at $8,500 \times g$ for $10 \mathrm{~min}$.

Complete procedure for purification of TuMV

Based on the above results, an improved procedure recommendable for purification of TuMV was established as shown in Fig. 2.

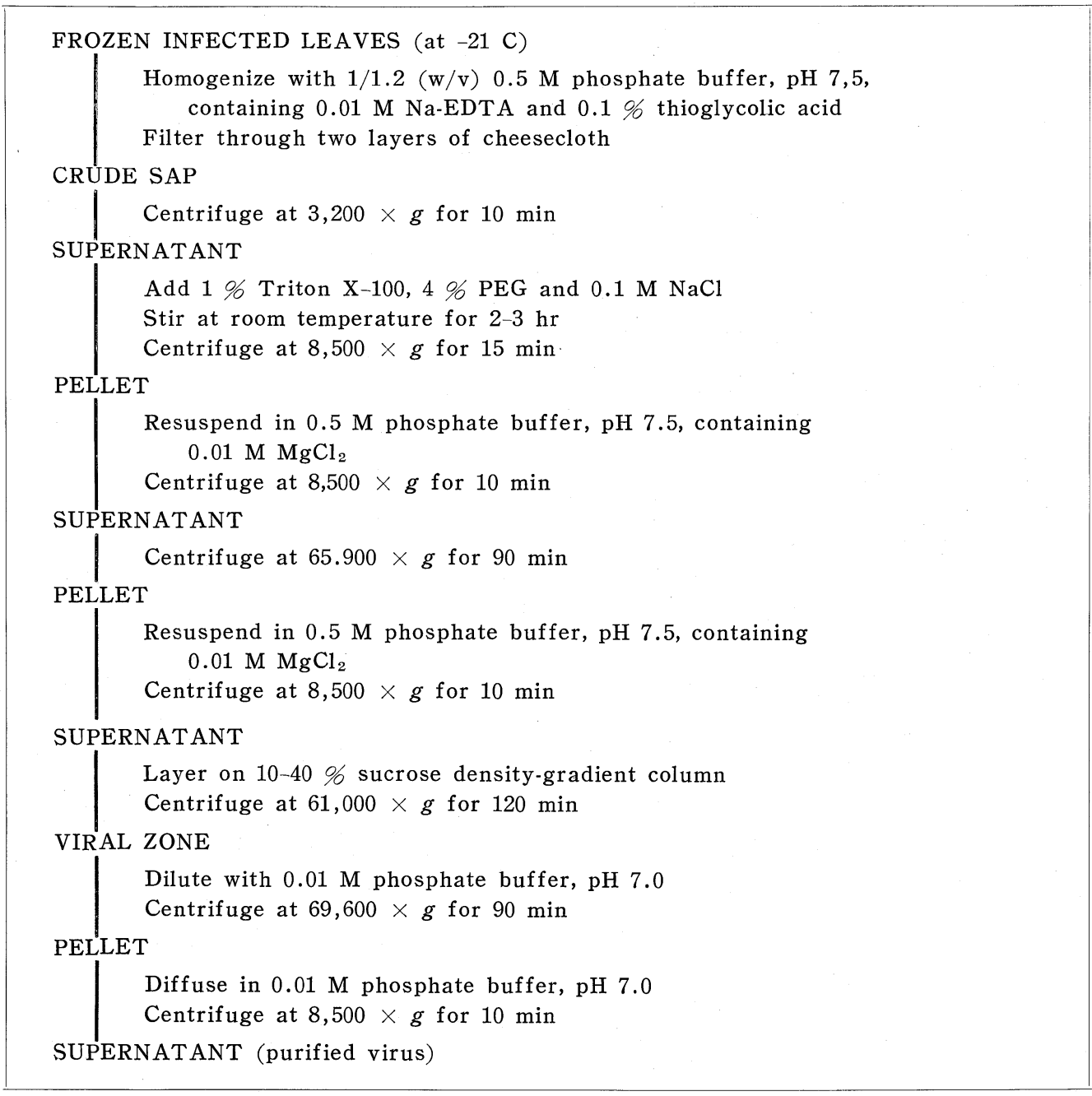

Fig. 2. Procedures for purification of TuMV. All procedures except for Triton X-100 / PEG / NaCl treatment were done at $4 \mathrm{C}$.

\section{Ultraviolet absorption of purified TuMV}

The TuMV preparation purified by the procedure mentioned above showed the ultraviolet absorption curve typical for nucleoprotein with UV absorption maximum at $260 \mathrm{~nm}$ and minimum at $247 \mathrm{~nm}$, as shown in Fig. 3. The ratio of O.D. 260 / O.D. 280 (not corrected for light-scattering) was 1.23 (average of 6 preparations with 1.20 - 


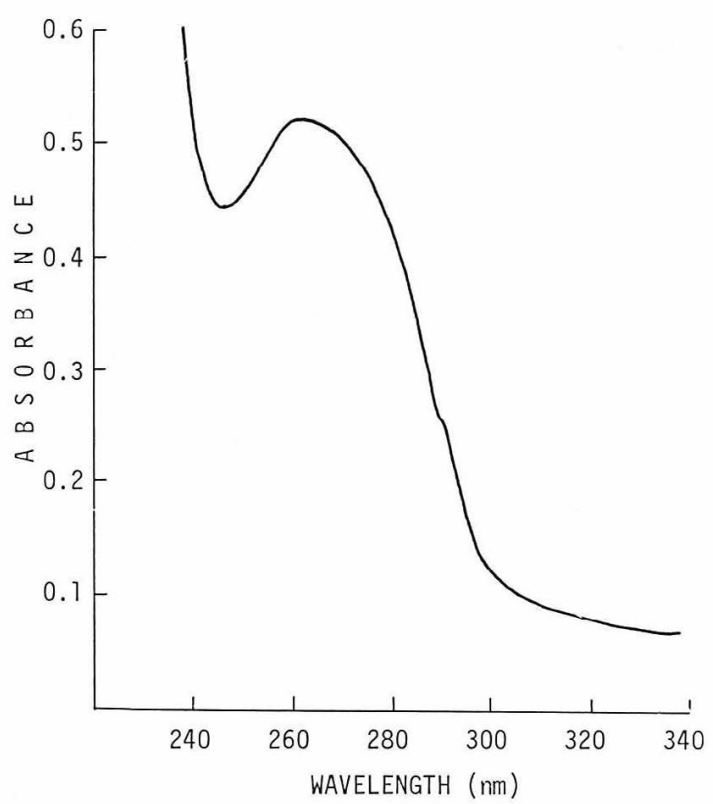

Fig. 3 Ultraviolet absorption spectrum of purified TuMV.
1.24). These characteristics coincide with those reported by StaceSmith and Tremaine ${ }^{20}$ ). The UV absorption spectrum showed a slight shoulder at $290 \mathrm{~nm}$ similar to that of maize dwarf mosaic virus $\left.{ }^{9}\right)$, which indicated the presence of tyrosine or tryptophan in the coat protein.

Based on the assumption that the common extinction coefficient 2.7 O. D. 260 unit is equivalent to 1 $\mathrm{mg} / \mathrm{ml}$ of virus in the case of PVY group $^{18,20)}$, the estimated yield of purified TuMV was $1.5-4.0 \mathrm{mg} /$ $100 \mathrm{~g}$ of infected leaves.

Electron microscopic observation of purified $T \boldsymbol{T} M \boldsymbol{V}$

The purified virus preparation was negatively stained with $2 \%$ potassium phosphotungstate, $\mathrm{pH}$ 7.0, and dropped on carboncoated grids. The observation was carried out under JEM-7 A electron microscope.

Electron micrograph (Fig. 4) showed unaggregated flexuous rod-shaped virus particles without any contaminants. The normal length of virus particles estimated in comparision with $300 \mathrm{~nm}$ of tobacco mosaic virus was about $745 \mathrm{~nm}$ (48\% of the particles out of 294 measured).

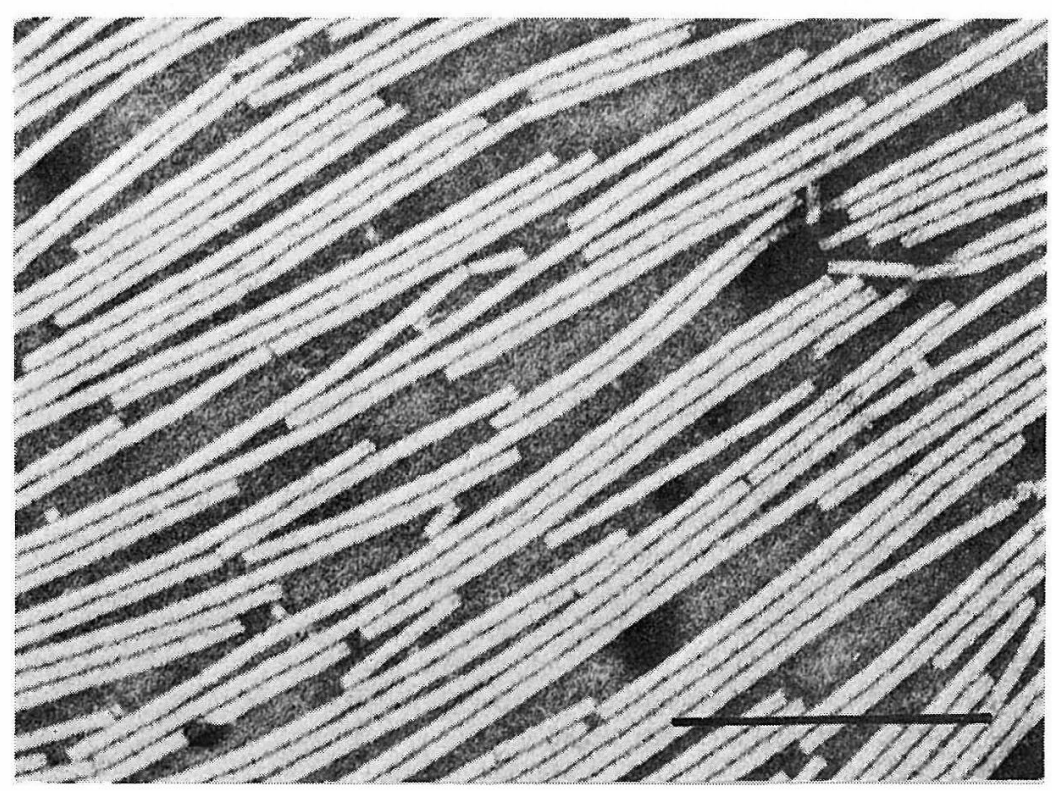

Fig. 4. Electron micrograph of purified TuMV.

Stained with $2 \%$ potassium phosphotungstate.

The scale represents $300 \mathrm{~nm}$. 


\section{Conclusion}

Aggregation is a serious problem which frequently occurs during the course of purification of PVY group viruses ${ }^{3,11,19)}$. Generally, two types of aggregation, viz. aggregation with hydrophobic bonds of virus particles and that mediated with host materials are considered to occur. In these aggregations, the latter seems more serious than the former during the course of virus purification.

Shepherd and Pound ${ }^{19}$ ) had efficiently extracted TuMV by preventing aggregation with $0.5 \mathrm{M}$ phosphate buffer. The similar result was also obtained in our experiment. Tomlinson ${ }^{23}$ ) reported that phosphate buffer was unsuitable for extraction of flexuous rod-shaped viruses as compared with borate buffer, however, the extraction with potassium phosphate buffer resulted in a greater yield than with borate buffer in the case of TuMV, which coincided with the result of Shepherd and Pound 19). The tight aggregation of virus particles which mainly occurs by means of PEG precipitation mediated with host plant constituents as reported by Hull and Shephe$\mathrm{rd}^{8)}$ caused serious loss of the virus. In order to prevent such an aggregation, Triton X-100 has been successfully used in the purification of some other viruses ${ }^{8,13}$. We confirmed in this experiment that simultaneous application of $1 \%$ Triton $\mathrm{X}-100$, $4 \% \mathrm{PEG}$, and $0.1 \mathrm{M} \mathrm{NaCl}$ prevented the tight aggregation to produce easily resuspendable pellet and in due course gave a greater yield of unaggregated virus than in the case of PEG or Triton X-100 alone.

Usually, low molarity buffer has been used for resuspending pellet obtained by PEG precipitation or high-speed centrifugation. Recently Luisoni et al. ${ }^{11}$ ) reported that high molarity buffer markedly avoided aggregation of poplar mosaic virus by giving a stable ionic strength to virus particles. The similar result was obtained in our experiment by using high molarity $(0.5 \mathrm{M})$ potassium phosphate buffer for resuspe-nding TuMV. The presence of $\mathrm{Mg}^{++}$ion or urea in high molarity resuspending buffer increased the preventing effect of aggregation. It seems possible that these additives effectively prevent the aggregation of TuMV by their ability to break hydrophobic bonds as stated by Price ${ }^{17}$ ) and Damirdagh and Shepherd ${ }^{3)}$.

Since the purification scheme presented here was successfully applied to several isolates of TuMV, the method will contribute to put comparative studies on serological and chemical characteristics of the isolates in practice.

\section{Literature cited}

1. Bar-Joseph, M. and Hull, R. (1974) Virology $62: 552-562$

2. Corbett, M. K. (1961) Ibid. $15: 8-15$

3. Damirdagh, I. S. and Shepherd, R. J. (1970) Phytopathology $60: 132-142$

4. De Sequeira, D. A. and Lister, R. M. (1969) Ibid. $59: 1740-1749$

5. Gordon, O. T. and Gingery, R. E. (1973) Ibid. $63: 1386-1392$

6. Hebert, T. T. (1963) Ibid. $53: 362$

7. Hill, J. H., Ford, R. E. and Beuner, H. (1973) J. gen. Virol. 20:327-339

8. Hull, R. and Shepherd, R. J. (1976) Ibid. $31: 93-100$

9. Jones, K. K. and Tolin, S. A. (1972) Phytopathology $62: 812-816$

10. Lister, R. M. and Hadidi, A. F. (1971) Virology $45: 240-251$

11. Luisoni, E., Boccardo, G. and Milne, R. G. (1976) Phytopath. Z. $85: 65-73$

12. Milne, R. G., Conti, M. and Lisa, V. (1973) Virology $53: 130-141$

13. Nozu, Y. and Yamamura, R. (1971) Ibid. $43: 514-515$

14. Papa, G., Michelin-Lausarat, P. and Castta, A. (1973) Phytopath. Z. $78: 344-356$

15. Pirone, T. P. and Lous Angalone, J. (1966) Phytopathology $56: 371-372$

16. Pirone, T. P., Pound, G. S. and Shepherd, R. J. (1960) Nature $186: 656-657$ 
17. Price, W. C. (1963) Advan. Virus Res. $10: 171-216$

18. Purcifull, D. E. (1966) Virology $29: 8-14$

19. Shepherd, R. J. and Pound, G. S. (1960) Phytopathology $50: 797-803$

20. Stace-Smith, R. and Tremaine, J. H. (1970) Ibid. $60: 1785-1789$

21. Sun, M. K. C. and Hebert, T. T. (1972) Ibid. 62:832-839

22. Tochihara, H. (1959) Ann. Phytopath. Soc. Japan $24: 287-295$

23. Tomlinson, J. A. (1963) Nature 200:93-94

24. Uyeda, I., Kojima, M. and Murayama, O. (1975) Ann. Phytopath. Soc. Japan 41 : 192-203

25. Yoshii, H., Sugiura, M. and Iwata, T. (1963) Mem. Assoc. Pl. Prot. Kyushu, No. 1 : 1-26

和 文 摘 要

\section{カブモザイクウイルスの純化方法について}

崔＼cjkstart璋京・前田孚憲・脇本 哲

当教室保存のカブモザイクウイルス（TuMV，分離株 No. 67）を用いて TuMV の純化方法を検討した。 凍結処理した罹病カブ 葉を $0.5 \mathrm{M}$ りん酸緩衝液（0.01 M EDTA，0.1\%チオグリコール酸を含む， $\mathrm{pH}$ 7.5) 中で磨砕し, ガーゼでろ過後, 低速遠心により得た上澄に $1 \%$ Triton X-100，4\% PEG (MW6,000) 及び $0.1 \mathrm{M} \mathrm{NaCl}$ を同時に加えることによりウイルスを強固に凝集させることなく清澄化と濃縮を行った。

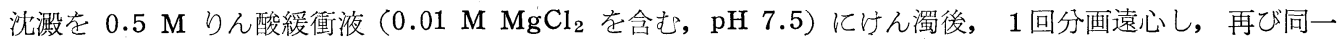
緩衝液にけん濁後しょ糖密度勾配遠心によりウイルスを純化した。純化ウイルス標品の紫外線吸収は典型

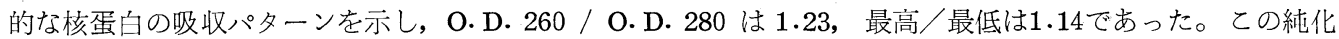
ウイルスは電顕観察でも夾雑物を含まないことを確認した。純化ウイルスの収量は罹病葉 $100 \mathrm{~g}$ 当り $1.5 \sim 4.0$ $\mathrm{mg}$ と推定された。 